\title{
Molecular Cloning and Expression of the Coagulase Gene of Staphylococcus aureus 8325-4
}

\author{
By PRASART PHONIMDAENG, MARY O'REILLY, PAUL W. O'TOOLE \\ AND TIMOTHY J. FOSTER* \\ Microbiology Department, Moyne Institute, Trinity College, Dublin 2, Ireland
}

(Received 23 June 1987; revised 8 September 1987)

\begin{abstract}
The gene coding for coagulase (coa) was cloned from Staphylococcus aureus 8325-4 in a $\lambda$ replacement vector in Escherichia coli. Coagulase (plasma-clotting) activity was measured in $\lambda$ coa lysates and an immunoreactive protein of $60 \mathrm{kDa}$ was detected by Western immunoblotting with anti-coagulase serum. This protein comigrated with the major immunoreactive protein in supernatants of $S$. aureus 8325-4. The coa gene was subcloned in pUC vectors. One recombinant expressed a $60 \mathrm{kDa}$ immunoreactive protein and plasma-clotting activity. A putative $\beta$-galactosidase-coagulase fusion protein and truncated peptides were expressed by variants formed by subcloning. These results are consistent with previously published biochemical data that the prothrombin-binding domain of coagulase is located in the $\mathrm{N}$ terminus of the protein. The cloned coa gene was transferred into $S$. aureus on a shuttle plasmid. Expression of coagulase was higher in a strain with a mutation in the agr locus, which controls the level of several exoproteins in $S$. aureus, suggesting that agr normally regulates coagulase expression negatively.
\end{abstract}

\section{INTRODUCTION}

Staphylococcus aureus is a Gram-positive pathogenic bacterium which causes a variety of human tissue infections including furuncles, wound sepsis, osteomyelitis and endocarditis (for reviews see McCartney \& Arbuthnott, 1978; Easmon \& Adlam, 1983a, b). It is also the major cause of mastitis, an economically important disease of dairy cattle (Anderson, 1983).

The organism produces an array of extracellular and cell-bound proteins which are potentially important in pathogenesis (for reviews see McCartney \& Arbuthnott, 1978; Easmon \& Adlam, $1983 \mathrm{~b}$ ). Coagulase is one such protein (Jeljaszewicz et al., 1983). It has the ability to stimulate the clotting reaction of plasma. This is often used to identify $S$. aureus and to distinguish it from less pathogenic species of staphylococci. Coagulase-negative strains are less virulent than the coagulase-positive $S$. aureus (Kinsman \& Arbuthnott, 1980) and it has long been inferred that coagulase is a virulence factor. This is supported by the observations that coagulase-deficient mutants of $S$. aureus are less virulent for mice (Haraldsson \& Jonsson, 1984; Hasegawa \& San Clemente, 1978; Jonsson et al., 1985; Masuda, 1983) and that the purified protein can cause pathological changes in laboratory animals (Anderson et al., 1982; Smith \& Johnstone, 1958).

Coagulase is an extracellular protein which stimulates the clotting reaction in plasma by forming a stoichiometric, non-covalent complex with prothrombin (Hemker et al., 1975). In contrast to the activation of prothrombin by blood-clotting factor $\mathrm{Xa}$ to form thrombin, the formation of staphylothrombin does not involve proteolytic cleavage of the blood protein (Hemker et al., 1975). The prothrombin-binding and procoagulant regions of coagulase have been located in the amino terminus of the protein by analysis of chymotrypsin fragments (Kawabata et al., 1986a,b).

The expression of some extracellular proteins by $S$. aureus is dependent on a regulatory locus called agr (Bjorklind \& Arvidson, 1980; Recsei et al., 1986). In agr-like regulatory mutants of 


\section{Table 1. Bacterial strains}

Strain Genotype

S. aureus 8325-4 $\operatorname{coa}^{+} \operatorname{agr}^{+}$

RN4220

$\cos ^{+}$

ISP546

$\operatorname{coa}^{+}$agr :: $\operatorname{Tn} 551$

E. coli

C600

TB1 lac thr leu thi tonA hspR hspM ara thi rpsL $\triangle$ lac-pro ${ }_{\mathrm{XIII}}$ ( $\phi 80 \mathrm{~d}$ lacl $\Delta \mathrm{M} 15)$ hspR
Relevant properties

$$
\begin{aligned}
& \text { NCTC } 8325 \text { cured of prophages. } \\
& \text { Plasmid-free } \\
& \text { Mutant of } 8325-4 \text { capable of accept- } \\
& \text { ing shuttle plasmids from E. coli } \\
& \text { Mutant of } 8325-4
\end{aligned}
$$

Host for detecting chimaeric pUC plasmids
Source and reference

Novick (1963)

Kreiswirth et al. (1983)

Brown \& Pattee (1980)

Recsei et al. (1986)

Appleyard (1954)

Yanish-Perron et al. (1985)

strain V8 both protein $\mathrm{A}$ and coagulase were derepressed, suggesting that expression is negatively regulated (Bjorklind \& Arvidson, 1980).

In order to facilitate molecular genetic analysis of coagulase production we have cloned the coagulase gene from $S$. aureus $8325-4$ in phage $\lambda$ and plasmid vectors in $E$. coli. Several truncated and fusion derivatives of coagulase were isolated and their ability to stimulate the clotting reaction was tested. A shuttle plasmid carrying coa was constructed and transferred into $S$. aureus strains allowing regulation of coagulase expression to be examined.

\section{METHODS}

Bacterial strains, plasmids and phages. The bacterial strains are listed in Table 1 and the plasmids in Table 2. The replacement vector $\lambda \mathrm{L} 47.1$ (Loenen \& Brammar, 1980) was used to clone the coa gene. Transduction in $S$. aureus was done using phage $80 \alpha$ (obtained from H. Pomeroy, Microbiology Department, Trinity College, Dublin, Ireland).

Bacteriological media. E. coli strains were grown in L broth and L agar (Miller, 1972) while $S$. aureus was routinely cultured in Trypticase Soy Broth and Agar (BBL). $\lambda$ phages were propagated in $\lambda$ base and top agar (Miller, 1972). Brain heart infusion broth (BHI) (Oxoid) was used for culturing $S$. aureus to measure coagulase expression in culture supernatants.

Chemicals, antibiotics and enzymes. Laboratory chemicals were obtained from Sigma or were the best grade available from BDH. Ampicillin (Ap) was a gift from Beecham. Chloramphenicol (Cm), erythromycin (Em) and tetracycline ( $\mathrm{Tc}$ ) were purchased from Sigma. Restriction enzymes and T4 DNA ligase were obtained from Boehringer and were used according to the manufacturer's instructions. Coagulase protein purified from $S$. aureus CN6708 (Anderson et al., 1982) was a gift from Dr C. Adlam (Wellcome, Beckenham, Kent, UK).

Assay for coagulase. Coagulase in $S$. aureus culture supernatants was measured as follows. Dilutions of supernatants $(0.5 \mathrm{ml})$ were added to $0.5 \mathrm{ml}$ of rabbit plasma diluted $1: 3$ in phosphate-buffered saline (PBS). The titre was the reciprocal of the highest dilution showing evidence of clotting after $24 \mathrm{~h}$ incubation at $37^{\circ} \mathrm{C}$ (Anderson et al., 1982). In the case of E. coli strains carrying pCOA plasmids, cells from cultures grown for $16 \mathrm{~h}$ were concentrated 100-fold and lysed by the procedure used for plasmid DNA preparation (Maniatis et al., 1982). After lysis, benzamidine $(2 \mathrm{mM})$ and phenylmethylsulphonyl fluoride $(2 \mathrm{~mm})$ were added. A $30 \mu \mathrm{l}$ sample was diluted in $0.5 \mathrm{ml}$ PBS. Doubling dilutions were made in PBS and $0.5 \mathrm{ml}$ volumes were added to $0.5 \mathrm{ml}$ of rabbit plasma diluted as above. Coagulase expressed by $\lambda$ coa was measured in dilutions of lysates prepared as described previously (O’Toole \& Foster, 1986a).

Antisera. Anti-coagulase serum raised in rabbits against coagulase purified from strain CN6708 was a gift from Dr C. Adlam. Before use in tests with recombinant phages or plasmids in $E$. coli the serum was adsorbed with a concentrated extract of E. coli $\mathrm{C} 600$. Peroxidase-conjugated swine anti-rabbit globulin was purchased from Dakopatts (Glostrup, Denmark). Peroxidase-conjugated protein A was obtained from Sigma.

Plaque and colony immunoblotting. $\lambda$ plaques producing coagulase were detected by laying $82 \mathrm{~mm}$ nitrocellulose discs (Schleicher and Schuell) onto phage overlay plates. The filters were incubated successively with bovine albumin (Sigma), sheep plasma adsorbed with an extract of $E$. coli $\mathrm{C} 600$, rabbit anti-coagulase serum and peroxidase-conjugated swine anti-rabbit immunoglobulin serum, according to the procedure described by Russell et al. (1985). Sheep plasma was included to block protein-A-producing recombinants. Expression of coagulase by E. coli colonies was detected by the immunoblotting procedure of Helfman et al. (1983). 


\section{Table 2. Plasmids}

\begin{tabular}{|c|c|c|}
\hline Plasmid & Host & Marker(s) \\
\hline $\begin{array}{l}\text { pBR322 } \\
\text { pUC18 } \\
\text { pUC19 } \\
\text { pSK265 } \\
\text { pCA1 }\end{array}$ & $\begin{array}{l}\text { E. coli } \\
\text { E. coli } \\
\text { E. coli } \\
\text { S. aureus } \\
\text { Shuttle }\end{array}$ & $\begin{array}{l}A p^{r} T c^{r} \\
A p^{r} \\
A p^{r} \\
C m^{r} \\
A p^{r} C^{r}\end{array}$ \\
\hline pCOA1 & E. coli & $A p^{r}$ \\
\hline pCOA2 & E. coli & $\mathrm{Ap}^{r}$ \\
\hline pCOA4 & Shuttle & $\mathrm{Ap}^{\mathrm{r}} \mathrm{Cm}^{\mathrm{r}}$ \\
\hline pCOA5 & E. coli & $A p^{r}$ \\
\hline pCOA6 & E. coli & $\mathrm{Ap}^{\mathrm{r}}$ \\
\hline pCOA7 & E. coli & $A p^{r}$ \\
\hline pCOA9 & E. coli & $A p^{r}$ \\
\hline pCOA10 & E. coli & $A p^{r}$ \\
\hline pCOA11 & E. coli & $A p^{r}$ \\
\hline $\mathrm{pCOA} 12$ & Shuttle & $\mathrm{Ap}^{r} \mathrm{Cm}^{\mathrm{r}}$ \\
\hline pCOA13 & E. coli & $A p^{r}$ \\
\hline pCOA14 & E. coli & $A p^{r}$ \\
\hline
\end{tabular}

Relevant properties

Cloning vector

Cloning vector

Cloning vector

Cloning vector

pBR322 linked to pSK265 at

EcoRI sites

$4.2 \mathrm{~kb} H i n d I I I$ fragment from

$\lambda$ coa cloned in pUC18

$4 \cdot 2 \mathrm{~kb} E c o \mathrm{RI}$ fragment from $\lambda c o a$ cloned in pUC19

$5 \cdot 2 \mathrm{~kb} K p n \mathrm{I}$ fragment from $\lambda c o a$ cloned in $\mathrm{pCAl}$

$5.2 \mathrm{~kb} K p n I$ fragment from pCOA4 in pUC19

$2.7 \mathrm{~kb}$ HincII fragment from pCOA5 in pUC19

Deletion of $0.85 \mathrm{~kb}$ and $1.9 \mathrm{~kb}$

AccI fragment from pCOA5

Deletion of $0.75 \mathrm{~kb} \mathrm{XbaI}$

fragment from pCOA5

pCOA2 with EcoRI insert in

opposite orientation

$4.2 \mathrm{~kb}$ HindIII fragment from

$\lambda$ coa cloned in pBR322

$2 \mathrm{~kb}$ Sau3AI fragment of pC221

cloned in BamHI site of pCOA2

$0.95 \mathrm{~kb} E c o$ RI fragment deleted from pCOAl

$5.2 \mathrm{~kb} K p n I$ fragment from pCOA4 in pUC19. Opposite orientation to pCOA5
Source and reference

Bolivar et al. (1977)

Yanish-Perron et al. (1985)

Yanish-Perron et al. (1985)

Jones \& Khan (1986)

*Ap, ampicillin; $\mathrm{Tc}$, tetracycline; $\mathrm{Cm}$, chloramphenicol.

Immunochemical analysis of coagulase. Proteins produced in $\lambda$ coa lysates were prepared as described previously (O'Toole \& Foster, 1986a). Lysates of pCOA-plasmid-carrying strains of $E$. coli were prepared as described above. The supernatant of a $16 \mathrm{~h} \mathrm{BHI}$ broth culture of $S$. aureus was concentrated by precipitation in $50 \%$ saturation ammonium sulphate and dialysed against $1 \%(\mathrm{w} / \mathrm{v})$ glycine. Proteins were fractionated by SDS-PAGE (Laemmli, 1970 ) and subjected to Western immunoblotting (Burnette, 1981). Filters were incubated with anti-coagulase serum followed by peroxidase-conjugated protein $\mathrm{A}$.

Transformation. Plasmids were transformed into cells of E. coli $\mathrm{C} 600$ and TB1 made competent by $\mathrm{CaCl}_{2}$ treatment (Maniatis et al., 1982), and into protoplasts of S. aureus prepared according to the method of O'Reilly $e t$ al. (1986).

Molecular cloning. A library of $S$. aureus 8325-4 DNA was constructed in $\lambda$ L47.1 as described previously (O'Toole \& Foster, 1986a), except that the genomic DNA was cleaved partially with Sau3AI and the $\lambda$ replacement vector was cut with BamHI. Subcloning and restriction mapping experiments were done using standard procedures (Maniatis et al., 1982). Recombinant phages from the gene library were plated on E. coli C600 and plaques were screened by filter immunoblotting. Positively reacting plaques were picked, replated and tested for their reaction with pre-immune rabbit serum in order to ensure that the recombinant was not expressing protein A. One phage ( $\lambda c o a)$ was studied further: proteins present in a phage lysate were concentrated and tested for plasma-clotting activity and by Western immunoblotting.

\section{RESULTS}

\section{Analysis of phage-specified polypeptides}

$\lambda$ coa lysates expressed a coagulase titre of 64 . In addition, $\lambda$ coa produced a polypeptide which migrated at the same rate as the coagulase expressed in $S$. aureus $8325-4$ culture supernatants 
Table 3. Coagulase titres in E. coli lysates

Each titre is the reciprocal of the highest dilution showing evidence of clotting after $24 \mathrm{~h}$ incubation at $37^{\circ} \mathrm{C}$ (see Methods).

$\begin{array}{lc}\text { C600 } & \text { Coagulase titre* } \\ \lambda \text { coa } & <2 \\ \text { C600(pCOA1) } & 64 \\ \text { C600(pCOA2) } & 10240 \\ \text { C600(pCOA4) } & <2 \\ \text { C600(pCOA5) } & 1024 \\ \text { C600(pCOA6) } & 1024 \\ \text { C600(pCOA9) } & 512 \\ \text { C600(pCOA11) } & 4096 \\ \text { C600(pCOA14) } & 1024 \\ \end{array}$

* Nos are the means of three independent experiments.

(Fig. 1, tracks 6 and 7). It should be noted that although the coagulase proteins produced by strains 8325-4 and CN6708 cross-react immunologically, they migrate at slightly different positions in SDS-palyacrylamide gels (Fig. 1, tracks 1, 2, 6 and 7).

\section{Subcloning the coagulase gene in plasmid vectors and analysis of plasmid-specified polypeptides}

$\lambda$ coa DNA was cleaved with KpnI and ligated with KpnI-cut pUC19 vector DNA and transformed into E. coli strain TB1. Lac ${ }^{-}$colonies were picked and screened by colony immunoblotting using anti-coagulase serum as the primary antibody. Positively reacting colonies were shown to carry a $5 \cdot 2 \mathrm{~kb} \mathrm{KpnI}$ fragment from $\lambda$ coa. Recombinants having the insert in both orientations were found and one of each (pCOA5 and pCOA14) was kept for further analysis. Extracts of cells carrying these plasmids expressed plasma-clotting activity, although the titres differed (Table 3). Many attempts to detect an immunoreactive polypeptide in lysates of pCOA5-carrying cells failed, possibly due to poor expression or degradation, or both. However, an immunoreactive polypeptide which comigrated with the major protein in $S$. aureus 8325-4 culture supernatants was detected in extracts of $E$. coli carrying pCOA9, which was derived from pCOA5 by deleting a $0.7 \mathrm{~kb} X b a \mathrm{I}$ fragment (Fig. 1, tracks 5 and 7 ). This shows that the intact coa gene had been subcloned from the phage.

A $4.2 \mathrm{~kb}$ HindIII fragment from $\lambda$ coa and a $2.7 \mathrm{~kb}$ HincII fragment from pCOA5 were cloned into HindIII-cut and HincII-cut pUC19, forming pCOA1 and pCOA6, respectively. The HindIII fragment was also cloned into the HindIII site of pBR322 to form pCOA11. pCOA1-, pCOA11- and pCOA6-carrying cells reacted positively in colony immunoblotting tests with anti-coagulase serum and extracts clotted rabbit plasma with titres of 10240, 1024 and 512, respectively. However, none of the lysates contained the $60 \mathrm{kDa}$ polypeptide seen in $\lambda$ coa and pCOA9 extracts. pCOAl expressed immunoreactive proteins of $45 \mathrm{kDa}$ and $39 \mathrm{kDa}$ but repeated attempts to identify immunoreactive proteins in extracts of pCOA6 failed. pCOA 1 probably produces truncated coagulase peptides which retain immunoreactivity and functional activity. If this is the case, the HindIII site lies in the promoter-distal $3^{\prime}$ region of the coding sequence. pCOA6 presumably produces similar, but shorter, truncated polypeptides. Alignment of the cloned fragments with the restriction map of pCOA5 and $\lambda$ coa (Fig. 2) suggests that the coagulase-coding sequence spans the $0.9 \mathrm{~kb}$ EcoRI-HindIII fragment. If this is the case, transcription of the coa gene proceeds in the direction indicated in Fig. 2.

The location of the coa gene in pCOAl was confirmed by deleting a $0.9 \mathrm{~kb} E c o$ RI fragment (i.e. including the EcoRI-HindIII referred to above) to yield pCOA13 (Fig. 2). This plasmid did not express either clotting activity or an immunoreactive protein, showing that the coa gene is located in this region.

In order to localize coa more precisely a $4.2 \mathrm{~kb} E c o \mathrm{RI}$ fragment was subcloned from $\lambda$ coa into pUC19. Several immunoreactive colonies were purified for further analysis. All had the $4 \cdot 2 \mathrm{~kb}$ 


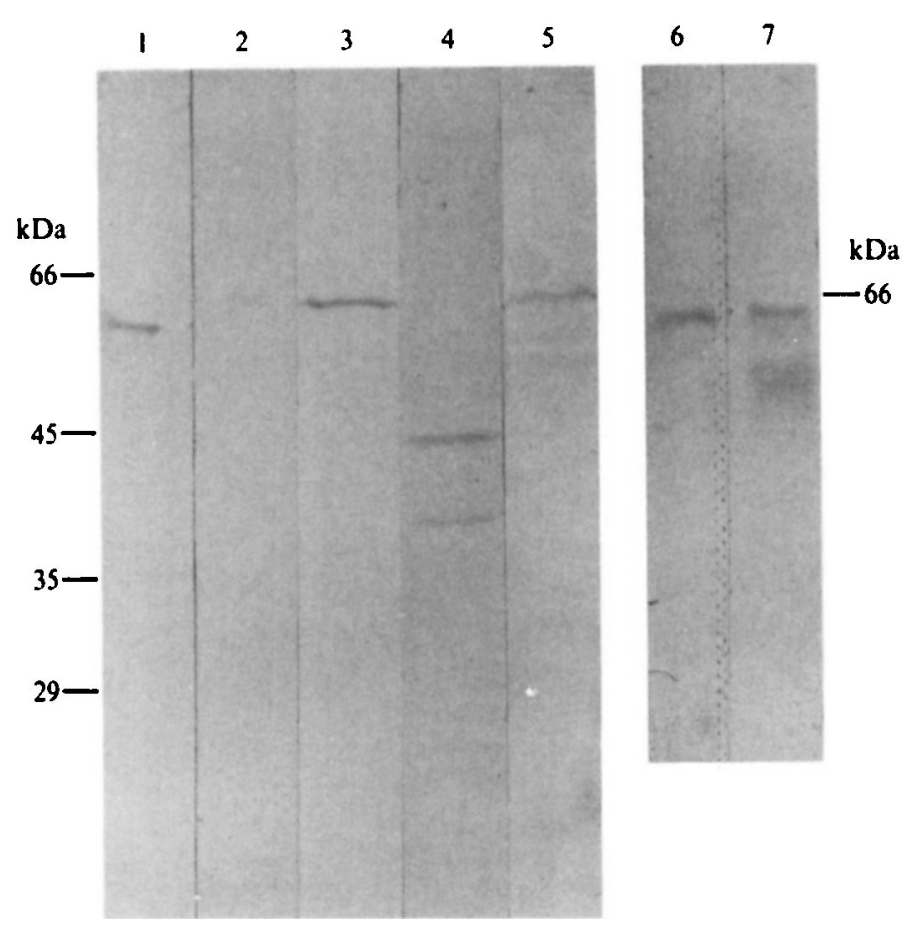

Fig. 1. Western immunoblots: lane 1, coagulase purified from strain CN6708 (12 $\mu \mathrm{g})$; lanes 2 and 6, $\lambda$ coa lysate $(80 \mu \mathrm{g}$ protein); lane 3 , lysate of $E$. coli(pCOA2) $(14 \mu \mathrm{g}$ protein); lane 4 , lysate of $E$. coli(pCOA1) (45 $\mu$ g protein); lane 5, lysate of $E$. coli(pCOA9) (47 $\mu \mathrm{g}$ protein); lane $7, S$. aureus $8325-4$ culture supernatant (13.5 $\mu \mathrm{g}$ protein).

$E c o$ RI fragment in the same orientation. A representative recombinant, pCOA2, expressed a polypeptide of $60 \mathrm{kDa}$ which reacted strongly with anti-coagulase serum but extracts lacked plasma-clotting activity.

The orientation of the inserted EcoRI fragment in pCOA2 was reversed. This plasmid (pCOA10) did not express the immunoreactive $60 \mathrm{kDa}$ protein. In addition, insertion of a $2 \mathrm{~kb}$ Sau3AI fragment from pC221 into the BamHI site located between the lac promoter of pUC19 and the EcoRI cloning site (forming pCOA12) eliminated expression of the $60 \mathrm{kDa}$ immunoreactive polypeptide. These results clearly demonstrated that expression of this protein is dependent on the vector's promoter, unlike coagulase produced by pCOA1 and pCOA5. It seems likely that the $60 \mathrm{kDa}$ protein is a hybrid formed between the $\mathrm{N}$-terminal residues of $\beta$ galactosidase and coagulase.

Two other plasmids were constructed which helped to confirm the location of the coa gene. pCOA7 was formed by deleting two AccI fragments from pCOA5, which eliminated both coagulase activity and immunoreactivity, whereas deleting the $0.7 \mathrm{~kb} X b a \mathrm{I}$ fragment of pCOA5 (to give pCOA9) did not affect either property.

\section{Expression of the cloned coa gene in $S$. aureus}

In order to investigate the regulation of expression of coagulase in $S$. aureus the $5.2 \mathrm{~kb} \mathrm{KpnI}$ fragment which carries the intact coagulase gene was cloned into the shuttle plasmid pCA1. This derivative (pCOA4) was initially selected in $E$. coli and then transformed into protoplasts of $S$. aureus RN4220. It was then transduced into $S$. aureus 8325-4 agr ${ }^{+}$and into ISP546 (agr::Tn551).

The level of expression of coagulase in broth culture supernatants was measured by titrating plasma-clotting activity (Table 4). The plasmid-free $a g r^{+}$strain 8325-4 expressed a low level of 


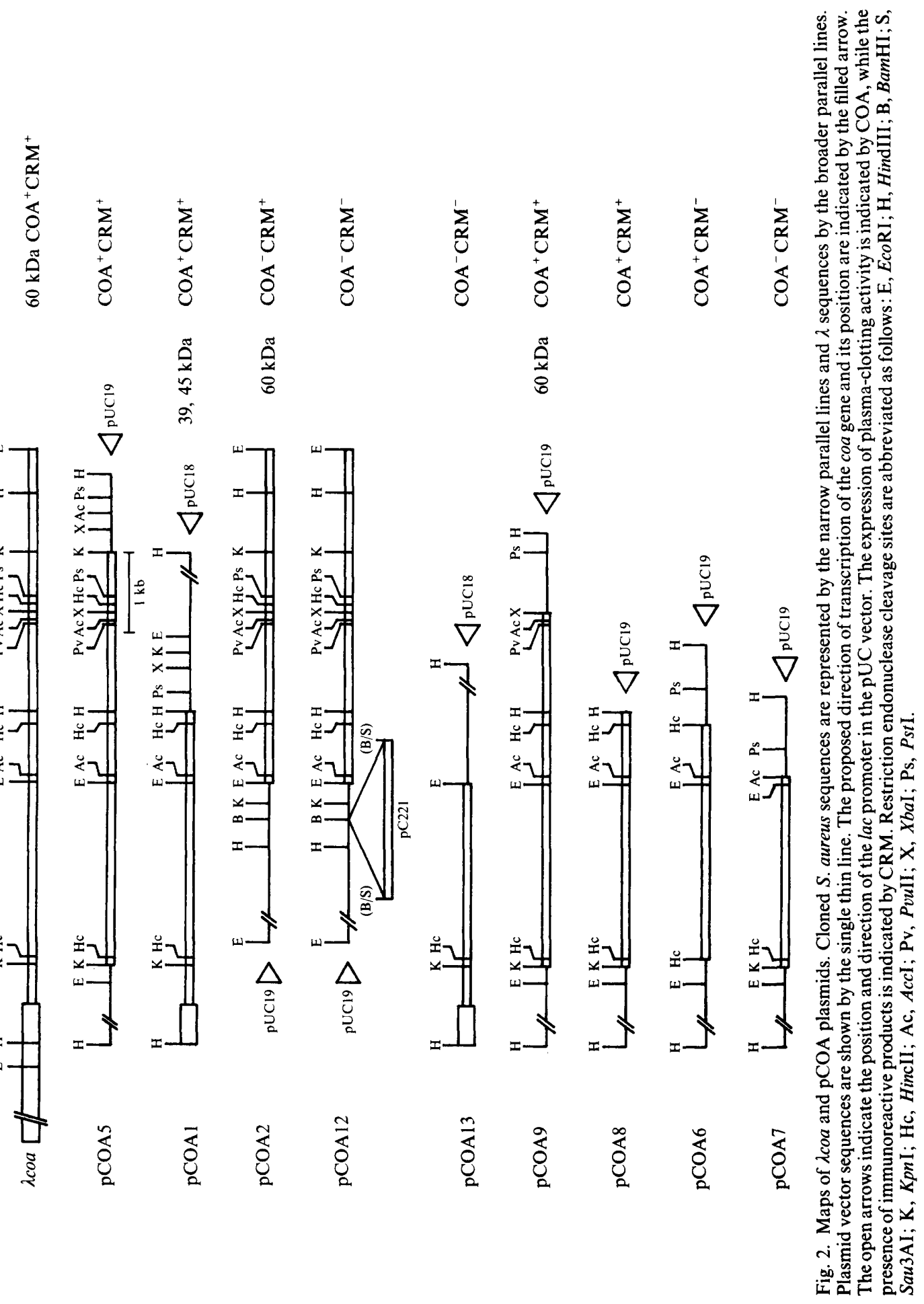


Table 4. Regulation of coagulase expression in $S$. aureus

Each titre is the reciprocal of the highest dilution showing evidence of clotting after $24 \mathrm{~h}$ incubation at $37^{\circ} \mathrm{C}$ (see Methods).

$\begin{array}{ccc}\text { Strain } & \overbrace{\text { Without plasmid }} & \text { Coagulase titre* } \\ 8325-4 & 51200 & 307200 \\ \text { ISP546 } & 307200 & 1024000 \\ \text { * Nos are the means of three independent experiments. }\end{array}$

coagulase compared to ISP546. When pCOA4 was introduced into 8325-4 and ISP546 the coagulase titres obtained were higher than those obtained with the plasmid-free strains (Table 4). Both these results are consistent with the hypothesis that the coagulase gene is negatively regulated by the agr system.

\section{DISCUSSION}

This paper reports the cloning and expression of the coagulase gene of $S$. aureus 8325-4. Lysates of $E$. coli formed by the growth of $\lambda$ coa produced an immunoreactive polypeptide band in SDS-polyacrylamide gels which comigrated with the major immunoreactive band in supernatants of early stationary phase cultures of $S$. aureus. The HindIII fragment in pCOA1 subcloned from $\lambda c o a$ expressed truncated immunoreactive proteins but retained plasma-clotting activity. This suggests that a HindIII site is located in the $3^{\prime}$ part of the coa gene. A deletion from a presumably more promoter-proximal HincII site also expressed coagulase and immunoreactive activity in colony blots. However, this protein was not detectable by Western immunoblotting.

In contrast, pCOA2 produced an immunoreactive peptide of $60 \mathrm{kDa}$ which lacked plasmaclotting activity. It is possible that this protein is a fusion between $\beta$-galactosidase from pUC19 and coagulase. Cloning at the $E c o$ RI site in pUC19 would generate a fusion protein in which the $\mathrm{N}$-terminal 22 amino acids of $\beta$-galactosidase are fused to coagulase lacking its $\mathrm{N}$-terminus. Expression would then be dependent on the vector's lac promoter and translation initiation signals. Elimination of expression of the $60 \mathrm{kDa}$ protein in insertion mutant pCOA12 is consistent with this. Fortuitously, this $l a c Z^{\prime}-c o a^{\prime}$ fusion protein is the same size as the mature staphylococcal coagulase.

The properties of the proteins expressed by $\mathrm{pCOA} 1, \mathrm{pCOA} 2$ and $\mathrm{pCOA} 12$ were consistent with biochemical data which showed that prothrombin-binding activity is located in the $\mathrm{N}$ terminus of coagulase (Kawabata et al., 1986a,b). An N-terminal $43 \mathrm{kDa}$ chymotrypsin fragment retained both prothrombin-binding and clotting activity, whereas shorter peptides lacking the $\mathrm{N}$-terminus lost the ability to clot plasma. DNA sequencing currently being done in this laboratory will determine if this is correct.

Coagulase activity was expressed by the KpnI and HindIII fragments subcloned from $\lambda$ coa irrespective of their orientation in pUC vectors. The coa promoter must be active in $E$. coli as are other S. aureus exoprotein gene promoters (O'Toole \& Foster, 1986a; Lofdahl et al., 1983; Kreiswirth et al., 1983), with the exception of those for epidermolytic toxin B (O'Toole \& Foster, $1986 b$ ) and enterotoxin B (Ranelli et al., 1985). There is no obvious explanation for the finding that coagulase was expressed at higher levels by pCOA5 where the lac promoter of the vector opposed the direction of coa transcription.

It has been reported that coagulase expression by strain V8 is regulated in a similar fashion to protein A because it is expressed predominantly during the exponential phase of growth and because higher titres are expressed by certain regulatory mutants (Bjorklind \& Arvidson, 1980). Here we show that an agr::Tn551 mutation in strain 8325-4 allows higher expression of coagulase than the agr ${ }^{+}$strain, both from the single copy chromosomal gene and when the 
strains harbour the coa gene on a multicopy plasmid. This is similar to the behaviour of the protein A (spa) gene (Uhlen et al., 1984; Patel et al., 1987) and is consistent with the suggestion that coa is negatively regulated by the product of the agr locus. However, it is not known if control is exerted at the level of the initiation of transcription of the coa gene. The cloned coa gene will be useful as a probe in Northern hybridization experiments. Also, it will be interesting to compare the promoter regions of the coa and spa genes for sequence similarities.

The cloning and mapping of the coagulase gene described here is facilitating the construction of specific coa mutations in virulent strains of $S$. aureus by recombinational allele replacement. This will permit the role of coagulase in the pathogenesis of staphylococcal infections to be determined.

This research was supported in part by the Wellcome Trust and was carried out in the framework of contract number BAP-0131-IRL of the Biotechnology Action Programme of the Commission of the European Communities. We thank Chris Adlam for generously supplying purified coagulase and antiserum.

\section{REFERENCES}

ANDERSON, J. C. (1983). Veterinary aspects of staphylococci. In Staphylococci and Staphylococcal Infections, Vol. 1, pp. 193-237. Edited by C. S. F. Easmon \& C. Adlam. London: Academic Press.

Anderson, J. C., Adlam, C. \& K Nights, J. M. (1982). The effect of staphylocoagulase in the mammary gland of the mouse. British Journal of Experimental Pathology 63, 336-340.

APPLEYARD, R. K. (1954). Segregation of new lysogenic types during growth of a doubly lysogenic strain derived from Escherichia coli K 12. Genetics 39, 440-452.

BJoRkLIND, A. \& ARvidson, S. (1980). Mutants of Staphylococcus aureus affected in the regulation of exoprotein synthesis. FEMS Microbiology Letters 7 , 203-206.

Bolivar, F., Rodriguez, R. L., Greene, P. J., Betlach, M. V., HEynecker, H. L., BOYeR, H. W., Crosa, J. H. \& Falkow, S. (1977). Construction and characterization of new cloning vehicles. II. A multipurpose cloning system. Gene 2, 95-113.

Brown, D. E. \& PATTEE, P. A. (1980). Identification of a chromosomal determinant of alpha-toxin production in Staphylococcus aureus. Infection and Immunity 30, 36-42.

BURNETTE, W. N. (1981) 'Western blotting': electrophoretic transfer of protein from sodium dodecyl sulphate polyacrylamide gels to unmodified nitrocellulose and radiographic detection with antibody and radioiodinated protein A. Analytical Biochemistry 112, 195-203.

EASMON, C. S. F. \& AdlaM, C. (1983a). Staphylococci and Staphylococcal Infections, Vol. 1. London: Academic Press.

Easmon, C. S. F. \& Adlam, C. (1983b). Staphylococci and Staphylococcal Infections, Vol. 2. London: Academic Press.

HARALDSSON, I. \& JoNSSON, P. (1984). Histopathology and pathogenesis of mouse mastitis induced with Staphylococcus aureus. Journal of Comparative Pathology 94, 183-196.

Hasegawa, N. \& San Clemente, C. L. (1978). Virulence and immunity of Staphylococcus aureus BB and certain deficient mutants. Infection and Immunity 22, 473-479.

Helfman, D. M., Fermamisco, J. R., Fiddes, J. C.,
Thomas, G. P. \& Hughes, S. H. (1983). Identification of clones that encode chicken tropomyosin by direct immunological screening of a cDNA expression library. Proceedings of the National Academy of Sciences of the United States of America 80, 31-35.

Hemker, H. C., Bas, B. M. \& MulleR, A. D. (1975). Activation of a pro-enzyme by a stoichiometric reaction with another protein. The reaction between prothrombin and staphylocoagulase. Biochimica et biophysica acta 379, 180-188.

Jeljaszewicz, J., Switalski, L. M. \& Adlam, C. (1983). Staphylocoagulase and clumping factor. In Staphylococci and Staphylococcal Infections, Vol. 2, pp. 525-557. Edited by C. S. F. Easmon \& C. Adlam. London: Academic Press.

Jones, C. L. \& Khan, S. A. (1986). Nucleotide sequence of the enterotoxin B gene from Staphylococcus aureus. Journal of Bacteriology 166, 29-33.

JoNsSON, P., LindBerg, M., HaRaldSSON, I. \& WADSTROM, T. (1985). Virulence of Staphylococcus aureus in a mouse mastitis model: studies of alpha hemolysin, coagulase, and protein $\mathrm{A}$ as possible virulence determinants with protoplast fusion and gene cloning. Infection and Immunity 49, 765-769.

Kawabata, S., Miyata, T., Morita, T., Miyata, T., IWANAGA, S. \& IGARISHI, H. (1986a). The amino acid sequence of the procoagulant- and prothrombinbinding domain isolated from staphylocoagulase. Journal of Biological Chemistry 261, 527-531.

Kawabata, S., Morita, T., Miyata, T., Iwanaga, S. \& IGARISHI, H. (1986b). Isolation and characterization of staphylocoagulase chymotryptic fragment. Journal of Biological Chemistry 261, 1427-1433.

Kinsman, O. S. \& ARButhNotT, J. P. (1980). Experimental staphylococcal infections in newborn mice: inhibition of weight gain as an index of virulence. Journal of Medical Microbiology 13, 281-290.

KreisWirth, B. N., LofDahl, S., Betley, M. J., O'Reilly, M., SCHLIEverT, P. M., Bergdoll, M. S. \& Novick, R. P. (1983). The toxic shock syndrome exotoxin structural gene is not detectably transmitted by a prophage. Nature, London 305, 709-712.

LAEMMLI, U. K. (1970). Cleavage of structural proteins during the assembly of the head of bacteriophage T4. Nature, London 227, 680-685.

Loenen, W. A. M. \& Brammar, W. J. (1980). A 
bacteriophage vector for cloning large restriction fragments made with several restriction enzymes. Gene 10, 249-259.

Lofdahl, S., Guss, B., Uhlen, M., Philipson, L. \& LINDBERG, M. (1983). Gene for staphylococcal protein A. Proceedings of the National Academy of Sciences of the United States of America 80, 697-701.

MCCARTNeY, C. \& ARbUTHNOTT, J. P. (1978). Mode of action of membrane-damaging toxins produced by staphylococci. In Bacterial Toxins and Cell Membranes, pp. 89-122. Edited by J. Jeljaszewicz \& T. Wadstrom. London: Academic Press.

Maniatis, T., Fritsch, E. F. \& SambrooK, J. (1982). Molecular Cloning: a Laboratory Manual. Cold Spring Harbor, NY: Cold Spring Harbor Laboratory.

Masuda, S. (1983). An efficient method for the isolation of a mutant with extremely low producibility of coagulase from a Staphylococcus aureus strain. Microbiology and Immunology 27, 801-805.

Miller, J. H. (1972). Experiments in Molecular Genetics. Cold Spring Harbor, NY: Cold Spring Harbor Laboratory.

Novick, R. P. (1963). Properties of a cryptic highfrequency transducing phage in Staphylococcus aureus. Virology 33, 155-166.

O'Reilly, M., de Azavedo, J. C. S., Kennedy, S. \& FosTER, T. J. (1986). Inactivation of the alphahaemolysin of Staphylococcus aureus $8325-4$ by sitedirected mutagenesis and studies on expression of its haemolysins. Microbial Pathogenesis 1, 125-138.

O'TOOLE, P. W. \& FosteR, T. J. (1986a). Molecular cloning and expression of the epidermolytic toxin A gene of Staphylococcus aureus. Microbial Pathogenesis 1, 583-594.
O'TOOLE, P. W. \& Foster, T. J. (1986b). Epidermolytic toxin serotype B of Staphylococcus aureus is plasmidencoded. FEMS Microbiology Letters 36, 311-314.

Patel, A. H., Nowlan, P., Weavers, E. D. \& Foster, T. J. (1987). Studies on the virulence of protein-Adeficient and $\alpha$-toxin-deficient mutants of Staphylococcus aureus isolated by allele replacement. Infection and Immunity 55, (in the Press).

RaNNELI, D. M., JoNes, C. L., Johns, M. B., Mussey, G. J. \& KhaN, S. A. (1985). Molecular cloning of staphylococcal enterotoxin B gene in Escherichia coli and Staphylococcus aureus. Proceedings of the National Academy of Sciences of the United States of America 82, 5850-5854.

Recsei, P., Kreiswirth, B., O'Reilly, M., SchlieVERT, P., GRUSS, A. \& Novick, R. P. (1986). Regulation of exoprotein gene expression in Staphylococcus aureus by agr. Molecular and General Genetics 202, 58-61.

Russell, R. R. B., Coleman, D. \& Dougan, G. (1985). Expression of a gene for glucan-binding protein from Streptococcus mutans in Escherichia coli. Journal of General Microbiology 131, 295-299.

SMith, D. D. \& Johnstone, J. M. (1958). Staphylocoagulase activity in vivo. British Journal of Experimental Pathology 39, 165-170.

Uhlen, M., Guss, B., Nilsson, B., Gotz, F. \& LiNDBERG, M. (1984). Expression of the gene encoding protein A in Staphylococcus aureus and coagulase-negative staphylococci. Journal of Bacteriology 159, 713-719.

Yanish-Perron, C., Vieira, J. C. \& Messing, J. (1985). Improved M13 phage cloning vectors and host strains: nucleotide sequences of $\mathrm{M} 13 \mathrm{mp} 18$ and pUC19 vectors. Gene 33, 103-119. 